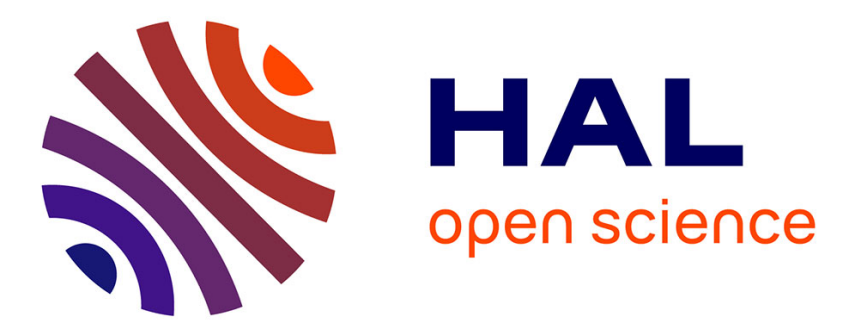

\title{
Surface migration of Staphylococcus xylosus on low-agar media
}

Emilie Dordet-Frisoni, Brigitte Gaillard-Martinie, Régine Talon, Sabine Leroy

\section{To cite this version:}

Emilie Dordet-Frisoni, Brigitte Gaillard-Martinie, Régine Talon, Sabine Leroy. Surface migration of Staphylococcus xylosus on low-agar media. Microbiological Research, 2008, 159 (4), pp.263-269. 10.1016/j.resmic.2008.02.003 . hal-01494735

\section{HAL Id: hal-01494735 \\ https://hal.science/hal-01494735}

Submitted on 23 Mar 2017

HAL is a multi-disciplinary open access archive for the deposit and dissemination of scientific research documents, whether they are published or not. The documents may come from teaching and research institutions in France or abroad, or from public or private research centers.
L'archive ouverte pluridisciplinaire HAL, est destinée au dépôt et à la diffusion de documents scientifiques de niveau recherche, publiés ou non, émanant des établissements d'enseignement et de recherche français ou étrangers, des laboratoires publics ou privés.

\section{다(1)(2)}

Distributed under a Creative Commons Attribution - ShareAlikel 4.0 International 


\title{
Surface migration of Staphylococcus xylosus on low-agar media
}

\author{
Emilie Dordet-Frisoni, Brigitte Gaillard-Martinie, Régine Talon, Sabine Leroy* \\ INRA, UR 454 Microbiologie, F-63122 Saint-Genès Champanelle, France
}

Received 7 August 2007; accepted 8 February 2008

Available online 10 March 2008

\begin{abstract}
Staphylococcus xylosus is a commensal species commonly found on the skin of mammals, but also currently used as starter culture for meat fermentation. Most strains of this species colonize by forming a biofilm on abiotic surfaces. We show here that the majority of $S$. xylosus strains also exhibit extensive colony spreading on the surface of soft agar media. This phenomenon seemed to be independent of biofilm-forming ability. It occurred in different culture media and was dependent on temperature. Formation of a giant $S$. xylosus colony did not involve a biosurfactant. Microscopic observation showed that the front of the giant colony comprised a single layer of spacing cells with more packed cells in the median area. Supplementation of the soft media with DNase I increased S. xylosus colony spreading, indicating that extracellular DNA may be involved in limiting the phenomenon. The ability of S. xylosus to spread on semi-solid surfaces may constitute an advantage for surface colonization. (C) 2008 Elsevier Masson SAS. All rights reserved.
\end{abstract}

Keywords: Staphylococcus xylosus; Motility; Giant colony

\section{Introduction}

It is increasingly believed that communities of bacteria act together rather than as a group of individual cells. It would be interesting to understand how these communities are formed and colonize a variety of natural habitats. Differing invasive behaviors are used by bacteria for the acquisition of nutrients, and motility constitutes a benefit. Many bacteria translocate by the propeller function of flagella [24]. Some bacteria, such as mycobacteria and streptococci, can spread on semi-solid surfaces without locomotor organelles [2,18]. A mechanism called sliding is generally used by these bacteria [9]. It is provided by the expansive forces of a growing culture in combination with special surface properties of the cells, resulting in reduced friction between the cell and its substrate [8]. Sliding motility results in a uniform sheet of closely packed cells in a single layer [9]. A phenomenon called darting has been observed in some staphylococcal species [9] and involves slow

\footnotetext{
* Corresponding author.

E-mail addresses: edordet@clermont.inra.fr (E. Dordet-Frisoni), brigitte. gaillard-martinie@clermont.inra.fr (B. Gaillard-Martinie), talon@clermont. inra.fr (R. Talon), sleroy@clermont.inra.fr (S. Leroy).
}

surface translocation produced by expansive forces developed in an aggregate of cells. Micromorphologically, cells or aggregates of cells are distributed randomly with empty areas in between [9]. In other Firmicutes, spreading motility independent of flagella was observed. In Bacillus subtilis, a sliding type of surface motility was detected in a non-flagellated mutant [13]. Secreted surfactin and extracellular potassium ions are required for spreading of B. subtilis [14]. Recently, rapid Staphylococcus aureus colony spreading on soft agar medium was reported [12]. Surface translocation of S. aureus differed from the darting of Staphylococcus epidermidis, involving slow surface translocation on solid agar medium, as described by Henrichsen [9].

Staphylococcus xylosus is a non-motile Gram-positive coccus belonging to the Staphylococcus saprophyticus group. S. xylosus is a common inhabitant of the skin of a variety of mammals and occasionally of humans [16]. This species is usually isolated from dairy and meat products [10] and $[3,17,21]$ is commonly used as starter culture for meat products [27]. It is also isolated from environmental sources such as surfaces in food processing plants or those of medical equipment $[1,4,5]$. It probably colonizes the skin and surfaces by forming a biofilm [23]. Surface translocation could also 
contribute to surface colonization. The capacity of S. xylosus to translocate from the site of inoculation on soft agar medium was first reported by Kloss et al. [15]. In the present study, we characterized the ability of $S$. xylosus to migrate widely on semi-solid surfaces, and we suggest an important role for extracellular DNA in cell-cell aggregation.

\section{Materials and methods}

\subsection{Strains and media}

The $S$. xylosus strains used in this study are listed in Table 1 . Bacteria were routinely grown in BHI (brain-heart infusion) broth (BD Becton, Dickinson and Company, Sparks, MD, USA) at $30{ }^{\circ} \mathrm{C}$ and with orbital shaking of $200 \mathrm{rpm}$.

\subsection{Spreading experiments}

Colony spreading was performed in BHI medium solidified with $0.4 \%$ w/v agar (Difco, Detroit, MI, USA). In some experiments, agar content varied between 0.3 and $1.5 \% \mathrm{w} / \mathrm{v}$. Colony spreading was also tested in two other media, Luria-Bertani (LB) medium containing $10 \mathrm{~g} / \mathrm{L}$ tryptone peptone (Difco), $5 \mathrm{~g} / \mathrm{L}$ yeast extract (Difco), $5 \mathrm{~g} / \mathrm{L} \mathrm{NaCl}(\mathrm{pH} 7.0$ ), and a minimal medium, MX medium developed specifically for the S. xylosus $\mathrm{C} 2 \mathrm{a}$ strain by Fiegler and Brückner [6] and containing (per L): $1 \mathrm{~g} \mathrm{Na}$-citrate $\cdot 2 \mathrm{H}_{2} \mathrm{O}, 7 \mathrm{~g} \mathrm{Na}_{2} \mathrm{HPO}_{4} \cdot 2 \mathrm{H}_{2} \mathrm{O}, 3 \mathrm{~g} \mathrm{KH}_{2} \mathrm{PO}_{4}$, $1 \mathrm{~g} \mathrm{NaCl}, 1 \mathrm{~g} \mathrm{KCl}, 4 \mathrm{~g}\left(\mathrm{NH}_{4}\right) 2 \mathrm{SO}_{4}, 0.5 \mathrm{~g} \mathrm{MgSO}_{4} \cdot 7 \mathrm{H}_{2} \mathrm{O}$, $0.0147 \mathrm{~g} \mathrm{CaCl} \cdot 2 \mathrm{H}_{2} \mathrm{O}$, three vitamins, $0.012 \mathrm{mg}$ biotin, $4.6 \mathrm{mg}$ nicotinic acid, $2 \mathrm{mg}$ thiamine hydrochloride and trace elements, $1.5 \mathrm{mg} \mathrm{FeCl}_{2} \cdot 4 \mathrm{H}_{2} \mathrm{O}, 0.07 \mathrm{mg} \mathrm{ZnCl}_{2}, 0.1 \mathrm{mg}$ $\mathrm{MnCl}_{2} \cdot 4 \mathrm{H}_{2} \mathrm{O}, 0.006 \mathrm{mg}$ boric acid, $0.19 \mathrm{mg} \quad \mathrm{CoCl}_{2}$, $0.002 \mathrm{mg} \quad \mathrm{CuCl}_{2} \cdot \mathrm{H}_{2} \mathrm{O}, \quad 0.024 \mathrm{mg} \quad \mathrm{NiCl}_{2} \cdot 6 \mathrm{H}_{2} \mathrm{O}$ and $0.036 \mathrm{mg} \mathrm{Na} 2 \mathrm{MoO}_{4} \cdot 2 \mathrm{H}_{2} \mathrm{O}$. Different carbon sources were added to MX medium: $5 \mathrm{~g} / \mathrm{L}$ of glucose, fructose or lactose. Media were autoclaved and $20 \mathrm{~mL}$ or $65 \mathrm{~mL}$ were poured into plates of 8.5 or $14 \mathrm{~cm}$ diameter, respectively. Plates containing agar medium were freshly prepared before inoculation and dried, open for $15 \mathrm{~min}$, in a laminar flow chamber. For standard tests, the centers of agar plates were inoculated in triplicate with $2 \mu \mathrm{l}$ of overnight culture containing approximately $10^{9} \mathrm{CFU} / \mathrm{mL}$. After inoculation, open plates were dried in a laminar flow chamber for $10 \mathrm{~min}$. The initial inoculum formed a spot with a diameter of $6 \mathrm{~mm}$. Unless indicated otherwise, plates were incubated at $25^{\circ} \mathrm{C}$ for up to $96 \mathrm{~h}$ before a negative reaction was recorded. Plates were photographed using a digital camera (Kodak EasyShare DX6490). In some cases, plates were inoculated from dilutions of overnight culture containing approximately $10^{7}, 10^{5}$ or $10^{3} \mathrm{CFU} / \mathrm{mL}$, or from $10 \times$ or $100 \times$ concentrated bacterial suspension obtained after centrifugation of overnight culture. In other experiments, the BHI and MX media were supplemented with different substances: $0.025 \%$ Tween $80,5 \mu \mathrm{g} / \mathrm{mL}$ surfactin from $B$. subtilis (Sigma-Aldrich, Saint Louis, MO, USA), 50 or $250 \mu \mathrm{g} /$ $\mathrm{mL}$ trypsin (Sigma-Aldrich), 90 units/mL DNase I (Roche, Mannheim, Germany) or $1 \mathrm{mg} / \mathrm{mL}$ DNase-free RNase A (Sigma-Aldrich). To measure spreading rates, the diameter
Table 1

S. xylosus strain ability to spread at $25^{\circ} \mathrm{C}$ on $0.4 \%$ agar BHI medium and to form biofilm on microplate test

\begin{tabular}{|c|c|c|c|}
\hline Strain & Origin & Spreading & Biofilm \\
\hline DSM20266 & Human skin & - & + \\
\hline DSM20267 & Human skin & - & + \\
\hline $\mathrm{C} 2 \mathrm{a}$ & DSM20267 cured & - & + \\
\hline 839 & Meat starter & ++ & - \\
\hline 840 & Meat starter & - & + \\
\hline S01002 & Meat starter & ++ & - \\
\hline S01003 & Meat starter & ++ & + \\
\hline S01004 & Meat starter & - & - \\
\hline S01006 & Meat starter & +++ & + \\
\hline S01007 & Meat starter & +++ & + \\
\hline S01008 & Meat starter & - & + \\
\hline S04002 & Meat starter & +++ & +++ \\
\hline S01001 & Dairy starter & + & + \\
\hline S04003 & Dairy starter & ++ & ++ \\
\hline S03187 & Sausage & +++ & ++ \\
\hline S03191 & Sausage & + & - \\
\hline S06173 & Raw milk & ++ & + \\
\hline S06171 & Cheese & ++ & + \\
\hline S06175 & Cheese & +++ & ++ \\
\hline S06176 & Cheese & + & +++ \\
\hline S06178 & Cheese & - & + \\
\hline S00290 & Environment of food plant & ++ & + \\
\hline S06167 & Environment of food plant & +++ & ++ \\
\hline S06179 & Environment of food plant & ++ & + \\
\hline S06186 & Environment of food plant & - & ++ \\
\hline S04009 & Cow mastitis & +++ & +++ \\
\hline S04010 & Cow mastitis & +++ & + \\
\hline S04012 & Cow mastitis & ++ & + \\
\hline S04013 & Cow mastitis & +++ & - \\
\hline S04016 & Cow mastitis & - & + \\
\hline S04017 & Cow mastitis & - & - \\
\hline S04018 & Cow mastitis & + & ++ \\
\hline S04011 & Goat mastitis & ++ & ++ \\
\hline S04014 & Goat mastitis & - & + \\
\hline S04019 & Goat mastitis & +++ & + \\
\hline S04020 & Goat mastitis & +++ & ++ \\
\hline S04021 & Goat mastitis & + & + \\
\hline $00-1747$ & Mouse dermatitis & - & ++ \\
\hline S07002 & Mouse & $+^{*}$ & ++ \\
\hline S07003 & Mouse & - & + \\
\hline S07001 & Poultry feces & ++ & ++ \\
\hline S07010 & Dog feces & - & - \\
\hline S07011 & Rabbit feces & + & + \\
\hline S06222 & Clinical, prosthetic heart valve & +++ & +++ \\
\hline S07005 & Clinical, endocarditis & $+^{*}$ & ++ \\
\hline S06223 & Clinical, liquid & ++ & ++ \\
\hline S06224 & Clinical, urine & ++ & ++ \\
\hline S07006 & Clinical, cerebrospinal fluid & ++ & ++ \\
\hline S07007 & Clinical, blood culture & ++ & ++ \\
\hline S07008 & Clinical, blood culture & + & +++ \\
\hline S06225 & Clinical, blood culture & ++ & ++ \\
\hline
\end{tabular}

*Strains spreading after $48 \mathrm{~h}$.

of the growth zone radiating from the point of inoculation on triplicate plates was measured each hour after surface migration commenced.

\subsection{Biofilm evaluation with crystal violet staining}

This assay is based on the colorimetric measure of crystal violet incorporated by sessile cells [22]. For each strain, 
$200 \mu \mathrm{l}$ of an overnight culture adjusted to $\mathrm{OD}_{600} 0.01$ was loaded into a 96-well polystyrene microtiter plate. As a control, $200 \mu \mathrm{l}$ of sterile BHI medium was used. The "non-biofilm-forming" strain Staphylococcus carnosus UT TM300 was employed as a negative control [7]. After $24 \mathrm{~h}$ of incubation at $30{ }^{\circ} \mathrm{C}$, the medium was removed and wells were washed once with $200 \mu \mathrm{l}$ sterile demineralized water to remove non-adherent bacteria. Two hundred $\mu$ per well of a $0.1 \%(\mathrm{v} / \mathrm{v})$ crystal violet solution in water (Merck, Fontenay-sous-bois, France) were added for $10 \mathrm{~min}$. After the staining step of adhered cells, the wells were washed two times with $200 \mu \mathrm{l}$ of sterile demineralized water to remove excess stain. The dye incorporated by the adherent cells was solubilized with $200 \mu \mathrm{l}$ of $33 \%$ (v/v) glacial acetic acid (SigmaAldricht, St Quentin Fallavier, France). One hundred and fifty $\mu \mathrm{l}$ of the solubilized solution or adapted dilution were transferred to a new microtiter plate. The OD of each well was measured at $595 \mathrm{~nm}$ using a microtiter plate reader (iEMS, Thermo Electron Corporation, Courtaboeuf, France). Absorbance was measured from the assay $\mathrm{OD}_{595}$ minus control $\mathrm{OD}_{595}$. The assay was performed at least in triplicate with four repeats for each strain.

\subsection{Microscopy observation}

One strain used as a model for spreading ability was grown for $16 \mathrm{~h}$ on $0.4 \%$ agar BHI medium. A giant colony on a plate was transferred directly to a glass coverslip. Optical microscopic analyses were performed using a phase-contrast Zeiss Axioplan 2E. For electron microscopic analyses, the cells on glass coverslips were fixed in $3 \%$ glutaraldehyde in $0.1 \mathrm{M}$ sodium cacodylate buffer $(\mathrm{pH} 7.4)$ at $4{ }^{\circ} \mathrm{C}$ for $1 \mathrm{~h}$, dehydrated using a graded ethanol and acetone series, placed on stubs and coated with gold in an EMSCOPE SC500, and observed with a SEM 505 Philips scanning microscope.

\section{Results}

\subsection{Screening of spreading phenomenon in S. xylosus strains}

Fifty-one S. xylosus strains described in Table 1 were inoculated on BHI low-agar medium plates at $30{ }^{\circ} \mathrm{C}$. Thirtyseven $S$. xylosus colonized the surface of the soft medium, after $16 \mathrm{~h}$ of incubation (Table 1 and Fig. 1). Fourteen strains did not spread from the point of inoculation and showed a $6 \mathrm{~mm}$ colony diameter, which was the size of the spotted area before incubation (Fig. 1B). Efficacy of spreading and shape of the resultant giant colonies were distinct for the different S. xylosus strains (Table 1 and Fig. 1). The majority of efficiently spreading strains formed a uniform surface film growth (Fig. 1A). Other morphologies were observed showing a fractal edge of migration (Fig. 1C) or protrusions (Fig. 1D-F). The less efficient strains usually spread with the formation of protrusions (Fig. 1E,F). The giant colonies varied in thickness. No correspondence between ecological niches of S. xylosus strains and their spreading capacity was noticed.

\subsection{Culture conditions for S. xylosus spreading}

Four efficiently spreading S. xylosus strains, S04002, S04009, S06175 and S06222, were chosen to characterize colony spreading on semi-solid media. Four non-spreading $S$. $x y$ losus strains on agar $0.4 \%$ at $30^{\circ} \mathrm{C}$ in $\mathrm{BHI}$ medium, C2a, S04016, S07003 and S07010, were also tested in different conditions of growth. These selected S. xylosus strains were from various ecological niches (Table 1). Different agar concentrations were tested ranging from 0.3 to $1.5 \%$ of agar $(w / v)$ in BHI and LB media. S. xylosus strains S04002, S04009, S06175 and S06222 were spread on either LB or BHI medium. For these four strains, colony spreading was observed from 0.3 to $0.9 \%$ of agar, but above $0.5 \%$ of agar, a significant decrease in the size of surface migration was noticed. Optimal spreading was observed on $0.3-0.4 \%$ agar (wt/vol). Colony spreading was observed for S. xylosus S04009 and S04020 strains in MX medium containing glucose, lactose and fructose as carbon sources with $0.4 \%$ agar. The S06222 strain was not able to growth in MX medium containing fructose as carbon source, but spread on glucose and lactose MX medium. S. $x y$ losus S06175 did not grow in MX medium. S. xylosus strains which are able to spread on the MX medium spread less efficiently on this medium than on BHI or LB media due to a low rate of growth (data not shown). It is important to note that whatever the media, colony spreading decreased when the period of plate drying before inoculation was prolonged (data not shown). The surface migration of the four spreading S. xylosus strains was observed at different temperatures ranging from $10{ }^{\circ} \mathrm{C}$ to $42{ }^{\circ} \mathrm{C}$. The strains showed good growth at all tested temperatures (data not shown). For all four strains, surface migration was observed at temperatures ranging from $20^{\circ} \mathrm{C}$ to $35^{\circ} \mathrm{C}$, except for strain S04009 which spread up to $37^{\circ} \mathrm{C}$, with an optimum between $25^{\circ} \mathrm{C}$ to $30^{\circ} \mathrm{C}$. At $10^{\circ} \mathrm{C}$, cellular translocation was slow and was observed after almost $48 \mathrm{~h}$ of incubation.

Non-spreading S. xylosus strains C2a, S04016, S07003 and S07010 were not able to spread whatever the agar concentration, media or temperature of growth used.

Kinetic measurements under optimal conditions for $S$. xylosus spreading (BHI medium solidified with $0.4 \%$ of agar, $25{ }^{\circ} \mathrm{C}$ ) indicated that the diameters of the growth zone did not increase between 0 and $6 \mathrm{~h}$ for the four spreading strains, after which the growth zone diameter increased continuously and rapidly, reaching speeds of $126,97,144$ and $63 \mu \mathrm{m} / \mathrm{min}$ for S04002, S04009, S06175 and S06222 strains, respectively.

To investigate whether initial cell density influenced surface migration, we tested different bacterial inocula. The overnight culture of S04002, S04009, S06175 and S06222 was 100 - or 10,000 -fold diluted in BHI broth, or 10- or 100-fold concentrated. Two $\mu$ l of these suspensions or pellets were spotted. No differences in colony spreading were observed after inoculation of the dense cell suspensions. The start of spreading was delayed with the diluted suspensions. 

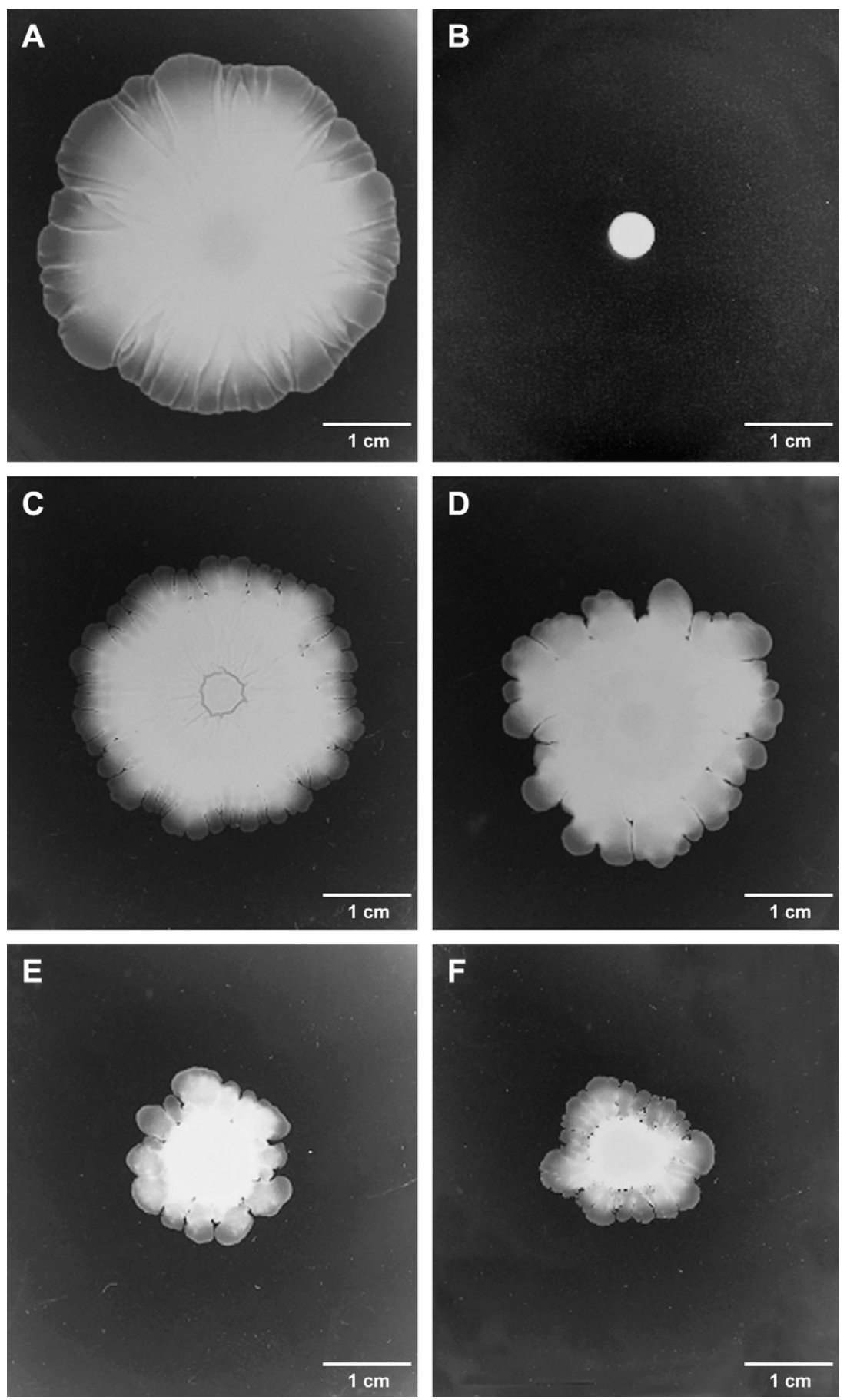

Fig. 1. Surface colonization by S. xylosus strains on low-agar medium plates. Two $\mu 1$ of overnight cultures were spotted in the center of $0.4 \%$ agar BHI medium and incubated at $25^{\circ} \mathrm{C}$ for $16 \mathrm{~h}$. (A) Spreading growth zone of strain S04002; (B) growth on non-spreading C2a strain; (C), (D), (E) and (F) spreading growth zone of strains S04011, 839, S04018, and S01001, respectively.

\subsection{Absence of a biosurfactant}

To examine the mechanism of surface migration, we tested for production of a surfactant that could increase the wettability of the agar surface. We were unable to detect surfactant in S. xylosus cultures of strains S04002, S04009, S06175 and S06222 by the drop collapsing test of Jain et al. [11]. Moreover, $10 \mu \mathrm{l}$ water drops applied to the surface of the agar medium near the edge of the giant colonies did not cause water spotting, confirming the absence of a surfactant. The addition of Tween 80, an anionic surfactant, resulted in disruption of surface film growth and formation of some protrusions of the spreading strains (data not shown) and did not promote spreading of non-motile strains C2a, S04016, S07003 and S07010. Supplementation of BHI with surfactin did not influence growth but decreased the spreading of S04002, S04009, 
S06175 and S06222 strains. It did not induce the formation of giant colonies by C2a, S04016, S07003 and S07010 strains (data not shown).

\subsection{Molecules which increase the S. xylosus rate of surface migration}

Spreading of S. xylosus S04002, S04009, S06175 and S06222 was weakly enhanced by the addition of trypsin to BHI medium (data not shown). An increase in the trypsin concentration increased the rate of colony surface migration. The addition of DNase I but not RNase A to the BHI medium strongly enhanced the surface film growth of the four efficient strains. The surface of the $14 \mathrm{~cm}$ diameter plate was completely covered after $22 \mathrm{~h}$ of growth on DNase I-supplemented BHI medium for S04002, $25 \mathrm{~h}$ for S06175 and $30 \mathrm{~h}$ for S04009 and S06222. Speeds of spreading were increased and were $175,143,167$ and $138 \mu \mathrm{m} / \mathrm{min}$ for $\mathrm{S} 04002$, S04009, S06175 and S06222 strains, respectively. The giant colonies were thinner on media supplemented with DNase I (data not shown). The same observation was made when DNase I was added to MX medium containing glucose for the three spreading strains which can grow on this medium. Trypsin and DNase I did not induce spreading in the four nonspreading S. xylosus strains.

\subsection{Correlation with biofilm formation}

To determine whether colony spreading ability and biofilm formation were related to each other, we evaluated the capacity of the 51 strains to form biofilm (Table 1). Quantification of biofilms was performed by a colorimetric measure of sessile cells stained by crystal violet. A large majority of $S$. xylosus strains formed biofilm in polystyrene microplates (Table 1). Only seven strains were biofilm-negative in our experimental conditions. Among these seven strains, four strains spread at different rates on semi-solid media. Three of the fourteen non-spreading strains did not form biofilm. The highly efficient spreading S. xylosus strains showed various biofilmforming capacities, with one strain unable to form biofilm or strains forming biofilm at different rates.

\subsection{Microscopic observations}

To examine the giant colony morphology of S. xylosus, optical and electron microscopic analyses were performed on spreading strain S. xylosus S04002. Optical microscopic observations of the edge of the giant colony on low-agar medium showed a monolayer of cells with spaces between the cells. In the median zone, cells seemed to be more packed (data not shown). This observation was confirmed by electron microscopy (Fig. 2A,B). In the median growth area of the giant colony, cells were aggregated in multiple layers separated by intercellular spaces (Fig. 2B). When the giant colony was formed on medium supplemented with DNase I, the appearance of the median zone was clearly modified and showed few or no aggregated cells (Fig. 2C).
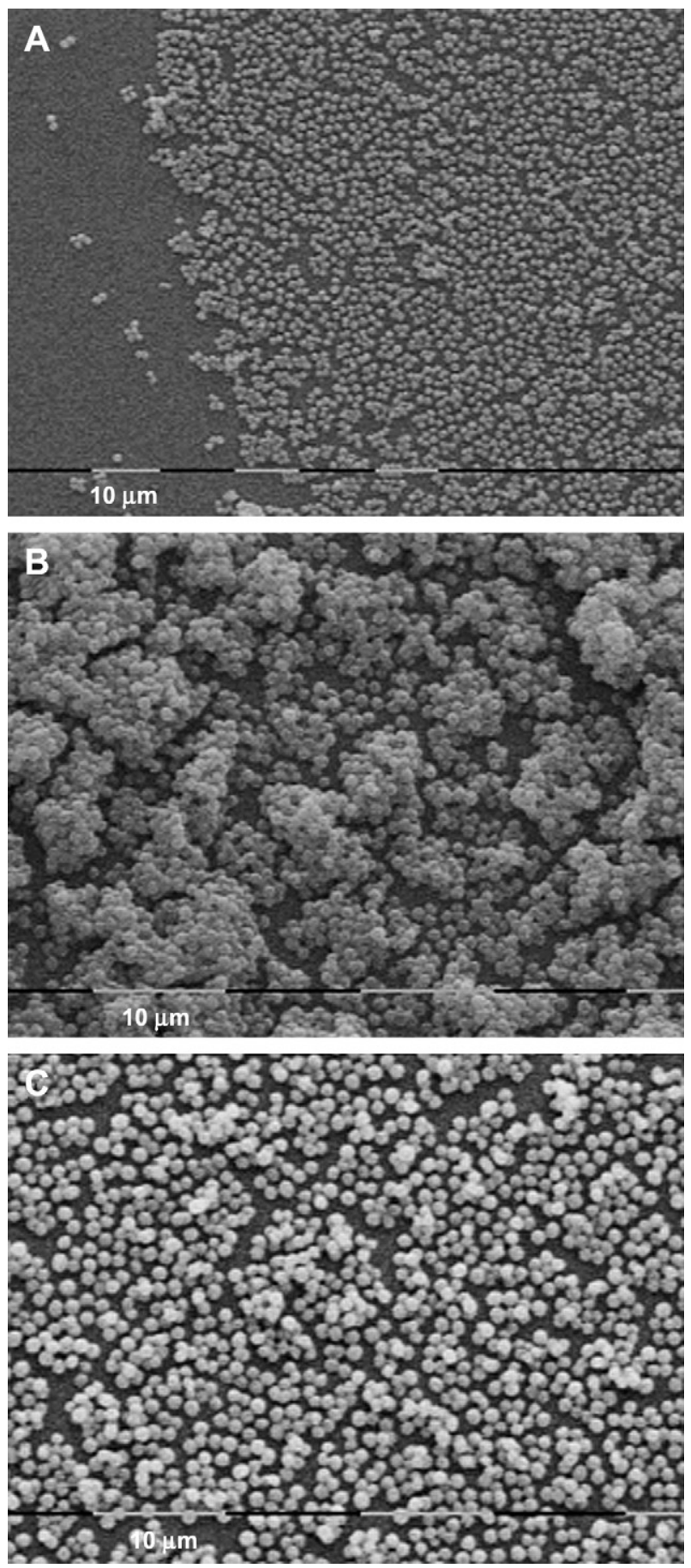

Fig. 2. Electron microscopic observations of the edge (A) and median growth area of a giant colony of S. xylosus S04002 strain formed at $25{ }^{\circ} \mathrm{C}$ on $0.4 \%$ agar BHI supplemented (C) or not (B) with DNase I.

\section{Discussion}

The majority of S. xylosus strains, independently of their origin, spread rapidly on a soft agar medium surface, colonizing the entire surface available. The average size of the giant colonies was dependent on the strain, agar concentration, temperature and time of incubation. Spreading growth of $S$. xylosus was optimally observed on $0.3-0.4 \%$ agar media between 
$25^{\circ} \mathrm{C}$ to $30^{\circ} \mathrm{C}$. Surface translocation was limited above $35^{\circ} \mathrm{C}$ and inhibited above $37^{\circ} \mathrm{C}$. The two rich BHI and LB media and minimal medium MX with various sources of carbon supported spreading of S. xylosus strains. Spreading behavior was thus independent of the growth medium and did not require amino acids, glucose or complex nutrients. Some strains of S. aureus can spread rapidly on low-agar medium [12]. Unlike S. xylosus, $40{ }^{\circ} \mathrm{C}$ was the optimum temperature for surface translocation of $S$. aureus. No spreading of $S$. aureus was observed below $30^{\circ} \mathrm{C}$ or when LB medium was used. Moreover, microscopic analyses revealed that the micromorphology of a giant colony of S. xylosus was different from that of $S$. aureus. The edge of the $S$. xylosus colony comprised a single layer of spacing cells, while that of $S$. aureus consisted of closely packed cells in several layers [12]. The surface translocation of S. xylosus does not appear to correspond to any of the six known bacterial surface translocations described by Henrichsen [9].

The flagellum-independent spread could depend on the production of surfactants, which lower the surface tension of the water and enhance surface migration [13,19]. We were unable to detect a surfactant in $S$. xylosus giant colonies, but colony spreading of this species is probably facilitated by the wettability of the media, as drying of the surface media decreased the phenomenon. But the addition of Tween 80 , which is known to modify the surface tension of the medium and improve surface wettability [20], did not have a significant effect on $S$. xylosus colony spreading. Complementation of the medium with $B$. subtilis surfactin did not induce spreading in non-efficient strains and reduced the phenomenon in positive spreading strains.

Addition of trypsin, a serine protease, moderately improved the surface migration of $S$. xylosus strains, probably by limiting cell-cell adhesion due to proteins. But DNase I strongly enhanced S. xylosus surface translocation. DNase I acts upon single-chain and double-stranded DNA. It can prevent cell-cell aggregation, which might be induced by extracellular DNA (eDNA) [25]. In S. xylosus, the presence of DNase limited the formation of cell aggregates in the median area of the giant colony. Some bacteria, such as Pseudomonas aeruginosa and S. aureus, produce eDNA, which forms a matrix participating in cell-cell contact in biofilms [26,28]. We presume that eDNA reduces the spreading of $S$. xylosus. We had previously reported the ability of $S$. xylosus to form biofilms [23]. In this study, we have shown that most $S$. xylosus strains isolated from various niches can form biofilm on polystyrene surfaces. No clear correlation between spreading ability and biofilm formation can be established. Biofilm-forming S. xylosus strains may or may not spread on semi-solid medium, and conversely, spreading strains may or may not form biofilm. The mechanisms implicated in spreading seem to be independent of those implicated in biofilm formation in S. xylosus species.

Colony spreading could be of great benefit for S. xylosus, which is ubiquitous and colonizes naturally fermented food. The spreading motility of $S$. xylosus strains may provide some advantages for colonization of surfaces. The biological significance of the ability of $S$. xylosus to spread, and the spreading mechanisms, remain to be elucidated.

\section{Acknowledgements}

We wish to thank Young-Suk Won for providing the strain implicated in mouse dermatitis, Pascal Rainard for strains isolated from mastitis, Michèle Bes, Emmanuel Coton and Jacques Schrenzel for clinical strains, Andrea Laukovà for strains isolated from rabbit and dog, Thomas Rinsoz for the strain isolated from poultry and Christine Vernozy for strains isolated from mice. We would like to thank Brigitte Duclos for secretarial assistance and David Marsh for revision of the English. Emilie Dordet-Frisoni is the recipient of a fellowship of the French Ministry of "Education Nationale et Recherche".

\section{References}

[1] Arciola, C.R., Campoccia, D., An, Y.H., Baldassarri, L., Pirini, V., Donati, M.E., et al. (2006) Prevalence and antibiotic resistance of 15 minor staphylococcal species colonizing orthopedic implants. Int. J. Artif. Organs. 29, 395-401.

[2] Bergman, S., Selig, M., Collins, M.D., Farrow, J.A., Baron, E.J., Dickersin, G.R., et al. (1995) "Streptococcus milleri" strains displaying a gliding type of motility. Int. J. Syst. Bacteriol. 45, 235-239.

[3] Cocolin, L., Rantsiou, K., Iacumin, L., Urso, R., Cantoni, C., Comi, G. (2004) Study of the ecology of fresh sausages and characterization of populations of lactic acid bacteria by molecular methods. Appl. Environ. Microbiol. 70, 1883-1894.

[4] Corbière Morot-Bizot, S., Leroy, S., Talon, R. (2006) Staphylococcal community of a small unit manufacturing traditional dry fermented sausages. Int. J. Food Microbiol. 108, 210-217.

[5] Cunha Mde, L., Lopes, C.A., Rugolo, L.M., Chalita, L.V. (2002) Clinical significance of coagulase-negative staphylococci isolated from neonates. J. Pediatr. (Rio J). 78, 279-288.

[6] Fiegler, H., Bruckner, R. (1997) Identification of the serine acetyltransferase gene of Staphylococcus xylosus. FEMS Microbiol. Lett. 148, $181-187$.

[7] Götz, F. (2002) Staphylococcus and biofilms. Mol. Microbiol. 43, 1367-1378.

[8] Harshey, R.M. (2003) Bacterial motility on a surface: many ways to a common goal. Annu. Rev. Microbiol. 57, 249-273.

[9] Henrichsen, J. (1972) Bacterial surface translocation: a survey and a classification. Bacteriol. Rev. 36, 478-503.

[10] Irlinger, F., Morvan, A., Elsolh, N., Bergere, J.L. (1997) Taxonomic characterization of coagulase-negative staphylococci in ripening flora from traditional French cheeses. Syst. Appl. Microbiol. 20, 319-328.

[11] Jain, D., Collins-Thompson, D., Lee, H., Trevors, J. (1991) A dropcollapsing test for screening surfactant-producing. J. Microbiol. Methods $13,271-279$.

[12] Kaito, C., Sekimizu, K. (2007) Colony spreading in Staphylococcus aureus. J. Bacteriol. 189, 2553-2557.

[13] Kinsinger, R.F., Shirk, M.C., Fall, R. (2003) Rapid surface motility in Bacillus subtilis is dependent on extracellular surfactin and potassium ion. J. Bacteriol. 185, 5627-5631.

[14] Kinsinger, R.F., Kearns, D.B., Hale, M., Fall, R. (2005) Genetic requirements for potassium ion-dependent colony spreading in Bacillus subtilis. J. Bacteriol. 187, 8462-8469.

[15] Kloos, W.E., Schadewaldt, P., Schleifer, K.H. (1981). In: M.P. Starr, H. Stolp, H.G. Trüper, A. Balows, \& H.G. Schlegel (Eds.), The prokariotes. A handbook on habitats, isolation, and identification of bacteria (pp. 1548-1569). Berlin, Heidelberg: Springer Verlag.

[16] Kloos, W.E., Schleifer, K.H. (1986) Bergey's manual of systematic bacteriology. Baltimore, MD: Williams \& Wilkins. 1013-1035. 
[17] Martin, B., Garriga, M., Hugas, M., Bover-Cid, S., VecianaNogues, M.T., Aymerich, T. (2006) Molecular, technological and safety characterization of Gram-positive catalase-positive cocci from slightly fermented sausages. Int. J. Food Microbiol. 107, 148-158.

[18] Martinez, A., Torello, S., Kolter, R. (1999) Sliding motility in mycobacteria. J. Bacteriol. 181, 7331-7338.

[19] Matsuyama, T., Kaneda, K., Nakagawa, Y., Isa, K., Hara-Hotta, H., Yano, I. (1992) A novel extracellular cyclic lipopeptide which promotes flagellum-dependent and -independent spreading growth of Serratia marcescens. J. Bacteriol. 174, 1769-1776.

[20] Matsuyama, T., Bhasin, A., Harshey, R.M. (1995) Mutational analysis of flagellum-independent surface spreading of Serratia marcescens 274 on a low-agar medium. J. Bacteriol. 177, 987-991.

[21] Montel, M.C., Talon, R., Cantonnet, M., Fournaud, J. (1992) Identification of Staphylococcus from French dry sausage. Lett. Appl. Microbiol. 15, 73-77.

[22] Musk, D.J., Banko, D.A., Hergenrother, P.J. (2005) Iron salts perturb biofilm formation and disrupt existing biofilms of Pseudomonas aeruginosa. Chemical Biol. 12, 789-796.
[23] Planchon, S., Gaillard-Martinie, B., Dordet-Frisoni, E., BellonFontaine, M.N., Leroy, S., Labadie, J., et al. (2006) Formation of biofilm by Staphylococcus xylosus. Int. J. Food Microbiol. 109, 88-96.

[24] Rashid, M.H., Kornberg, A. (2000) Inorganic polyphosphate is needed for swimming, swarming, and twitching motilities of Pseudomonas aeruginosa. Proc. Natl. Acad. Sci. U.S.A. 97, 4885-4890.

[25] Renner, W.A., Jordan, M., Eppenberger, H.M., Leist, C. (2004) Cell-cell adhesion and aggregation: influence on the growth behavior of $\mathrm{CHO}$ cells. Biotechnol. Bioeng. 41, 188-193.

[26] Rice, K.C., Mann, E.E., Endres, J.L., Weiss, E.C., Cassat, J.E., Smeltzer, M.S., et al. (2007) The cidA murein hydrolase regulator contributes to DNA release and biofilm development in Staphylococcus aureus. Proc. Natl. Acad. Sci. U.S.A. 104, 8113-8118.

[27] Talon, R., Leroy-Sétrin, S., Fadda, S. (2002). In: F. Toldrá (Ed.), Research advances in quality of meat and meat products - Chapter 10, Research Signpost (pp. 175-191).

[28] Whitchurch, C.B., Tolker-Nielsen, T., Ragas, P.C., Mattick, J.S. (2002) Extracellular DNA required for bacterial biofilm formation. Science $295,1487$. 